This is an electronic reprint of the original article. This reprint may differ from the original in pagination and typographic detail.

Author(s): Töllinen, Aarne; Karjaluoto, Heikki

Title: $\quad$ Marketing communication metrics for social media

Year: $\quad 2011$

Version:

Please cite the original version:

Töllinen, A., \& Karjaluoto, H. (2011). Marketing communication metrics for social media. International Journal of Technology Marketing, 6(4), 316-330.

https://doi.org/10.1504/IJTMKT.2011.045911 10.1504/11.45911

All material supplied via JYX is protected by copyright and other intellectual property rights, and duplication or sale of all or part of any of the repository collections is not permitted, except that material may be duplicated by you for your research use or educational purposes in electronic or print form. You must obtain permission for any other use. Electronic or print copies may not be offered, whether for sale or otherwise to anyone who is not an authorised user. 


\title{
Marketing communication metrics for social media
}

\author{
Aarne Töllinen and Heikki Karjaluoto \\ Jyväskylä University School of business and Economics
}

\begin{abstract}
Author Note
Aarne Töllinen, School of Business and Economics, University Of Jyväskylä; Heikki Karjaluoto, School of Business and Economics, University Of Jyväskylä.

Correspondence concerning this article should be addressed Aarne Töllinen, School of Business and Economics, University of Jyväskylä, P.O.Box 35, 40014, Jyväskylä, FINLAND. E-mail: aarne.tollinen@jyu.fi, Phone: +358 406845193
\end{abstract}




\begin{abstract}
The objective of this paper is to develop a conceptual framework for measuring the effectiveness of social media marketing communications. With recent advances in information and communications technology, especially in social collaboration technologies, both academics and practitioners rethink whether the existing marketing communications performance metrics are still valid in the changing communications landscape, or is it time to devise entirely new metrics for measuring marketing communications performance.
\end{abstract}

The study emphasizes that marketing communications performance measurement metrics have developed towards a customer orientation. The findings further indicate that a) there is no broadly accepted opinion of a single critical performance indicator, and b) literature classifies social media marketing metrics in three groups: qualitative, quantitative and financial. The implications of the study point that the shift towards a digitized interactive marketing environment does not necessarily mean that a whole array of new measurement metrics is needed.

Key words: Marketing Communications, Social Media, Marketing Performance Measurement, Marketing Communication Metrics 
Is there a Need for new Marketing Communications Performance Metrics for Social Media?

In recent years social media has gained significant interest among marketing practitioners and academicians. It is increasingly being argued that we are in the midst of a new communication landscape (e.g. Kietzmann et al. 2011) as the roles of customer interaction and user-generated content (UGC) are emphasized in marketing communications (Dennis et al., 2009; Liu et al., 2011). This shift towards interactive communications is transforming the landscape from one-way to two-way communications in which customers are actively participating, or at least being asked to participate, in the communications loop. Thus, customer engagement has been recently listed as a top research priority for marketing academics (MSI, 2010).

In addition to customer engagement, the changing media landscape has led the Marketing Science Institute to call for research to create new frameworks and methods that link existing marketing metrics and marketing performance measures with new media (MSI, 2010, for research priorities concerning metrics see also MSI, 2000; 2002; 2004; 2008). Thus there is a real need for research related to marketing communications performance measurement in social media context, as researchers and managers pay increasingly attention to social media without a clear understanding of how effective the media is or how to measure it.

In this article we attempt to develop a framework for measuring the effectiveness of social media marketing communications. Specifically, our objective is to discuss whether the existing marketing communications performance metrics are still valid in the changing communications landscape. An interesting research question we ask is whether there is a need to rethink them or even to devise entirely new metrics? In order to answer this question, the study reviews and collates the literature on social media marketing, social media metrics, and marketing 
performance measurement. Literature is collected from the most recent social media books and articles, and from marketing performance measurement studies. A detailed study of this phenomenon is important insofar as it can throw light on a number of processes involved in scientific activity and the growth of knowledge in this field in general.

This paper is structured as follows. First, we trace the development of the academic marketing discussion related to social media and its main topics. Second, we review the literature on marketing performance measurement and state how increasing use of social media creates a strong need for both marketing performance measurement research and marketing performance measurement implementation in practice. We conclude with a discussion of the implications of our findings and outline possible topics for further research.

\section{Social media in marketing communications}

Companies have taken social media seriously on a strategy level and a large number of companies have begun to set a budget for social media marketing. Organizations sense that social media is a new, but permanent, environment for marketing (Weinberg and Pehlivan, 2011). Social media has changed marketing practices tremendously and constantly. While in the traditional online environment large media budgets were typically targetted at catching the customers' attention, in the new social media age power structures are different as power has shifted increasingly towards the media consumers. Against this backdrop, large media budgets no longer directly and positively correlate with large audiences and effectives business in the world of user-generated content and multidimensional interaction. Hanna et al. (2011) hit the nail on the head when stating that social media has transformed the internet from a platform for information to a platform for influence. 
Business is expected to invest $\$ 6$ billion in social media in 2011 (Aho Williamson, 2011) and inevitably the academic marketing literature has shown a growing interest in this new media landscape. Marketing journals have published special issues on social media (e.g. Business Horizons, 2011) and many top marketing journals (e.g. Journal of Marketing; European Journal of Marketing; Journal of Business Research; Journal of Advertising Research) have recently published articles covering social media.

Social media marketing has been investigated in marketing literature from various perspectives, including the viewpoints of viral marketing (Kaplan and Haenlain, 2010; Ho and Dempsey, 2009), word of mouth (Steffes and Burgee, 2009; Cheung and Rabjohn, 2008; Brown et al., 2007), ecosystem (Hanna et al., 2011), customer engagement and participation (Parent et al., 2011; Muñiz and Schau, 2011; Kaplan and Haenlain, 2011), marketing budgeting (Weinberg and Pehlivan, 2011), corporate internal communications (Hearn et al., 2009), organizational knowledge management (van Zyl, 2008), history and development (Boyd and Ellison, 2008; Kambil, 2008; Schibrowsky et al., 2007), conceptual studies (Karakas, 2009; Constantidines and Fountain, 2008), relationship marketing and customer interaction (Quinton and Harridge-March, 2010; Ozuem et al., 2008), and direct marketing (Palmer and Koenig-Lewis, 2009).

Social media is collaboratively produced and shared content published through the internet. The term refers to networked digital platforms, which are used in communication between human beings (Hearn et al., 2009). Parent et al. (2011) suggest that social media platforms differ from traditional Web applications by offering users a place for content creation, content upload, networking, conversing, media sharing and bookmarking. According to Kietzmann et al. (2011) social media is interactive sharing, co-creating, discussing and modifying user-generated content through mobile and web-based technologies. To sum up, compared to the first generation online 
media or to the offline media, with social media one could equally be a content creator and a content consumer. In social media, neither the customer nor the company is a king. The king is content.

Social media is often used as a synonym for the term "Web 2.0" (Palmer and KoenigLewis, 2009; Riegner, 2007; Weinberg and Pehlivan, 2011). According to Constantidines and Fountain (2008) the term "Web 2.0" refers to digital communication platforms, while the term "social media" refers to the social characteristics (participation, openness, conversation, seamless, communal) of those platforms. However, they state that the term" Web 2.0 " should be used as an umbrella term to include both technical features and characteristics. Kaplan and Haenlain (2010) suggest that although the term "Web 2.0" was not originally meant to describe a new technical era of the internet, it later acquired that meaning. According to them, because of the later development trend of the term "Web 2.0", the term "social media" should be preferred. On this basis, it seems that social media is similarly more than just Web 2.0. As Weinberg and Pehlivan (2011) discover, Web 2.0 consists of computer network-based platforms upon which social media applications run.

The two key characteristics of social media are user-generated content and customer interaction (van Zyl, 2009; Riegner, 2007), which should be considered as a goal for marketing communication in social media. Muñiz and Schau (2011) prefer the term consumer-generated content (CGC). The interrelationship between UGC and interaction is quite logical as without any interaction there is no UGC. Thus, content is the result of interaction.

Palmer and Koenig-Lewis (2009) propose that UGC is an opportunity for a new kind of marketing communication, but it also challenges companies to give power to customers and loosen their own control over the discussion. In the same vein, Hennig-Thurau et al. (2010) argue 
that in traditional media, companies may formulate and control their marketing communication messages in the way they wish, but in social media they may only participate in the conversation and interaction with customers. Weinberg and Pehlivan (2011) state that social media has properties to empower consumers and give them influence, enabling relationship building between organizations and customers. Kietzmann et al. (2011) argue that in the age of social media, corporate communication has been democratized as the power has been taken from companies' marketing and PR by individuals and communities.

Why should an organization encourage customers to create content? First, marketing communication created by customers has been proved to be more credible in customers' eyes than the messages promoted by an organization, and so to have a more powerful impact on decision making (Riegner, 2007). Second, UGC may increase customers' value experience, because of interactive and fluent customer service and better opportunities to participate in product and service creation process (Muñiz and Schau, 2011). Third, active interaction and customer based content creation helps companies to build long-term competitive advantages (Parent et al., 2011).

\section{Marketing communications performance measurement}

Marketing performance in its narrow sense refers to gaining calculable and provable results from marketing activities. Ambler et al. (2001) for example state that "performance" refers to the financial results gained from business activities. In this study performance is however seen as not only related to financial results (something to be measured in currency e.g. sales, profits, increase in shareholder value, cash flow), but also inclusive of non-financial (e.g. brand awareness, customer satisfaction, customer loyalty / retention) results from marketing activities. 
"Marketing" in turn refers to what the company does to turn prospects into customers and to satisfy customers and so create shareholder value (Ambler and Roberts, 2008). In the marketing literature, marketing performance measurement (or like Morgan et al. 2002 and Donthu and Yoo 1998 state, marketing performance assessment), has been discussed mainly from two angles: marketing productivity (the efficiency approach) and the marketing audit concept (the effectiveness approach) (Morgan et al., 2002). Although marketing performance measurement has long been a concern in marketing literature, productivity and measurement analyses in marketing have advanced only sporadically in academic research (Morgan et al., 2002). The history of marketing performance literature dates back to the 1940s. According to Sheth and Sisodia (2002) in its early years marketing productivity analysis focused mainly on cost analysis. The same trend continued in the 1950s and 1960s, when marketing performance was still analysed mainly from a cost accounting point of view (Seth and Sisodia, 2002). Later, market-oriented and especially customer-oriented objectives came under the spotlight (Rust et al., 2004). In the 1990s, the marketing measurability discussion exploded (Greenyer, 2006) and after the millennium the same trend has continued.

Companies have long attempted to identify marketing key performance indicators (KPI) in order to measure the impact and success of marketing (Hanna et al., 2011). Sidhu and Roberts (2008) argue that in marketing literature little is known about the need for marketing to work more closely with the reported accounting performance of the firm. According to their research, marketing and accounting should have a morphological relationship and both of them should play an important role in a company's business strategy. There have been several calls for research on how marketing and accounting interrelate in both theory and practice (Inglis, 2008). 
In future, marketers should gain financial discipline and derive credibility from accountants, while accountants should learn about the nature of the organization's assets from marketers.

Ambler et al. (2004) state that both practitioners and academics have shown an increasing interest in the assessment of marketing performance. The growing interest is understandable, because according to O'Sullivan et al. (2007) and O'Sullivan et al. (2009), the ability to measure marketing performance positively affects firm performance and reporting frequency mediates the relationship. On the other hand, as Seth and Sisodia (2001) state, marketing's fundamental problem is low productivity and especially lack of accountability. So although the strong connection between business strategy, marketing strategy and marketing performance measurement with firm performance is recommended and proven by marketing literature (see e.g. Vorhies and Morgan, 2003), in practice, marketing measurement is quite fragmented and non-systematic (Amler et al., 2004). Vorhies and Morgan (2003) write that organizing marketing activities in ways that fit the business's strategic type is associated with marketing effectiveness and with marketing efficiency.

Lukas et al. (2005) state that marketing literature's failure to incorporate current financial valuation techniques and properly demonstrate its contribution to accounting research, suggest that future research is needed. According to McManus and Guilding (2008) it appears that there is also considerable potential for accountants to draw on points of focus raised in the marketing literature to further advance marketing-focused accounting measures of performance. So marketing should collaborate with accounting both in academic research and business practice. According to Seth and Sisodia (2002) marketers can learn sophisticated cost accounting methods and the value of having well-defined rules and regulations governing its functions from accounting. They state that this could help marketers to become more productive and more 
effective. While this is a reasonable assertion, we would suggest that due to marketing being focused on generating future income, as compared to accounting being focused on the past, audit-based practices applying well-defined rules and regulations do not necessarily fit in with future-oriented marketing planning.

Recent advances in technology have created new opportunities for marketing and accounting integration (Phillips and Halliday, 2008). The digitized world has radically altered the ways in which firms can monitor their customers and collect data from their marketing communications. Gleaves et al. (2008) suggest that recent developments in marketing accounting measures, recent technological advancements in database management and increasing pressure on marketers to prove their worth are contributing to a need for more effective marketing / accounting synergy. Also according to O'Sullivan and Abela (2007) there have been several high-profile calls for more research in the area of marketing performance measurement. Modern corporations must adopt new technologies to build competitive advantage.

Hanna et al. (2011) raise an important point in saying that the social media era has changed companies' marketing communication as consumers increasingly adopt active roles in cocreating marketing. On the other hand, companies do not understand what performance indicators they should be measuring and how they should measure the new kind of interactive marketing communications. Even though the benefits of social media communication, UGC and digitized customer-seller interaction are proven and often accepted, practitioners are still insecure of how to measure the effects of the growth in interactive communication. Thus, business managers are uncertain how to allocate marketing effort and budget to social media (Weinberg and Pehlivan, 2011). 


\section{Marketing communications metrics}

Ambler et al. (2001) propose that "metrics" should be limited to performance measures which are high level, necessary, sufficient, unambiguous, and ideally, predictive. Thus, marketing metrics should be calculable, in quantitative form, and auditable - in other words, reliable and professionally sourced (Ambler, 2002).

When discussing marketing performance measurement metrics, we often realize that marketing inputs (costs) are much easier to track than the outputs of marketing. It is important to note that there is no universally applicable way to measure marketing performance (Seth and Sisodia, 2002). Even if the main metrics were common between companies, the measurement strategy has to be customized to comply with the company's strategy and marketing tactics. Marketing performance measurement has to be company related.

In general, marketing tactics should be based on objectives arising from marketing strategy. Furthermore, marketing strategy should be strongly based on company-level objectives and on business strategy. Marketing performance measurement has to be seen in the context of the whole company (Phillips and Halliday, 2008). To know whether the marketing objectives or whole company's business objectives are met or not, the company needs regular marketing measurement. As Ambler and Roberts (2008) propose, the first step in marketing performance measurement is to make the company's long and short term objectives explicit.

One challenge related to marketing performance measurement metrics relates to the short and long term effects of marketing actions. Some marketing actions may generate rapid short term outputs, while other actions may have an outcome only seen after a longer time. Ambler et al. (2004) suggest that brand equity could bridge this challenge. On the other hand, they point out that brand equity is often measured but rarely integrated into a formal measurement system. 
Seth and Sisodia (2002) raise an essential observation related to continuous change in business environments. They state that in marketing performance measurement, it is important to ensure that metrics do not yield spurious relationships. For example a firm's market share could increase because its competitor lost its customers and not because of an improvement in the firm's marketing communications. That is why it is important for a company to have multiple metrics.

As stated above, better marketing performance measurement means more cooperation with the accounting department. Sidhu and Roberts (2008) notice that because of the lack of shared marketing-accounting language, different objectives, different tools and different metrics, the cooperation demands special care. A major challenge is that the financial accounting domain is dominated by rules and law, unlike the marketing domain that does not even have commonly accepted basics.

Ambler et al. (2004) state that the simplest measurement model includes actions (inputs) and profits (outputs). In the real world however the links between action and results are often difficult to prove. That is why marketing a measurement model also needs intermediate metrics (e.g. awareness, attitudes, satisfaction), behaviours (e.g. purchases, loyalty, word of mouth) and competitive metrics (e.g. market share) (Ambler et al., 2004). Ambler et al. (2001) found 19 primary general metrics: awareness, perceived quality, consumer satisfaction, relevance to consumer, perceived differentiation, brand / product knowledge, number of new customers, loyalty / retention, conversions, (trade) customer satisfaction, perceived quality, number of new products, revenue of new products, margin of new products, sales, gross margins, profitability. These 19 metrics they categorize in 6 groups: consumer attitudes, consumer behaviour, trade customer, relative to competitor, innovation and accounting. 
The metrics that best summarize brand equity and market performance are sales information, market share, marketing investment (into the brand), relevant end user satisfaction, relative price, perceived product quality, customer retention, sales to new customers, share of turnover of the previous three years' products launched, product availability/distribution, a glossary of marketing and brand terminology, and relevant measures chosen by directors (Ambler, 2002).

During the $21^{\text {st }}$ century both academics and practitioners have sought the best single financial indicator for marketing performance measurement. Peppers and Rogers (2005) argue that return on customer (ROC) is the best key performance indicator. Reichheld (2003) in turn proposes a new loyalty metric called promoter, which measures the likelihood of a company's customers recommending the company to another person. Other candidates for the single solution or "silver metric" include shareholder value, discounted cash flow (also used as a synonym for net present value, brand valuation, customer lifetime value, and customer equity), or return on marketing investment (Ambler and Roberts, 2008). According to Ambler and Roberts (2008), any single silver metric is inadequate and marketing performance measurement always requires more than one indicator.

Many recent managerial marketing measurement publications are positive about marketing ROI (see e.g. Jeffery, 2010; Sterne, 2010; Lenskold, 2003; Powell et al., 2011; Blanchard, 2011; Thomas and Barlow, 2011; Turner and Shah, 2011; Moeller and Landry, 2009; Arikan, 2008), but Ambler and Roberts (2008) for example criticize the usage of the ROI concept related to marketing measurement. They state that ROI is a good tool for comparing alternative investments and even the American Marketing Association (AMA 2005:8) indentifies six ROI measures (incremental sales revenue, ratio of cost to revenue, cost per sale generated, changes of 
financial value of sales generated, cost of new customer, cost of old customer retention), but, according to Ambler and Roberts, none of those is really an ROI metric. They claim that ROI metrics promote underperformance and short-termism.

In our opinion this depends on how we look at the question of ROI. As ROI is the net return divided by the investment, and if taken literally, Ambler's and Robert's (2008) critique of the AMA's list is apt. On the other hand, if we consider ROI as an umbrella metric or more like a title for a financial metric category to track the performance of marketing actions in currency, ROI is a usable term in marketing performance discussion. In the same way, Rust et al. (2004) support the terms ROI and ROMI (Return on Marketing Investment), when they propose a conceptual marketing measurement model called "return on marketing".

Zahay and Griffin (2010) examine customer based performance metrics (such as customer lifetime value, customer retention and share of wallet) in association with the choice of generic positioning and segmentation strategies, while strategic positioning choices are indirectly associated with business growth performance. They further propose that companies should focus on long-term customer metrics (for example customer retention and customer lifetime value) to maximize the growth of the company.

Rust et al. (2004) point out that the past 40 years of customer-centred marketing theory and practice also reflects on marketing metrics, by adding the measures of customer satisfaction, market orientation, customer value, and customer lifetime value. They also note that in recent years the concept of brand equity has been challenged by a more customer-oriented concept, that is, customer equity. For example Gleaves et al. (2008) propose customer profitability (CP) as a metric that links accounting and marketing. 
In addition, Lukas et al. (2005) emphasize that marketing managers should pay attention to long-term measurement. However they accentuate that instead of customer-oriented metrics, marketers should focus more on shareholder value measurement using metrics like free cash flow, shareholder value added, economic value added, market value added, cash flow, return on investment, and cash value added. Although the shareholder value point of view is important in the marketing performance measurement context, the links between action and results are often difficult to prove and shareholder value difficult to directly quantify and measure. Thus marketing measurement models demand intermediate metrics (c.f. Ambler et al., 2004).

Customer profitability $(\mathrm{CP})$ is one of the keys to effective marketing and it has been a subject of increasing attention in recent years (McManus and Guilding, 2008; Sidhu and Roberts, 2008). CP is associated with the concepts of customer lifetime value and customer equity (Sidhu and Roberts, 2008). Gleaves et al. (2008 p. 837) condense the link between these three concepts as follows: "If, as is proposed in this paper, CP can be considered, with some adjustments, equivalent to the CLV over a period of one accounting year, it is possible to see the inter-relation of these two terms. Since CE is defined as the sum of all current and future customers' lifetime values, we can clearly link CE with CLV by adding the NPV of future customers to the sum of the individual CLVs of all existing customers."

McManus and Guilding (2008) found in their literature review that increased customer satisfaction will have a beneficial impact on a firm's financial performance especially in a longterm context. In our opinion this is a well-defined reason to measure customer satisfaction and to implement metrics like customer equity, customer profitability, customer lifetime value, and customer retention. 


\section{Social media marketing metrics}

From the company's point of view listening is even more important in social media than talking. After well-defined objectives and goal setting, which is the first phase of social media marketing (Powel et al., 2011; Thomas and Barlow, 2011; Blanchard, 2011; Turner and Shah, 2011; Sterne, 2010; Delahaye Paine, 2011), listening is the second step towards social media marketing measurement. Social media offers companies a new kind of environment for listening (Thomas and Barlow, 2011; Blanchard, 2011). Barlow and Thomas (2011) state that companies can listen to social media in five ways: searching (manually used search engines), monitoring (automated methods to search), alerting (automated alert based search), measuring (quantitative manual and automated monitoring), and mining (research based search).

Barlow and Thomas (2011) state that social media analytics is a fresh concept, but it is based on the old principles of business analytics: if you can analyse what is being said about your company, its products and services in its business environment, you can reset your marketing objectives more precisely and plan your marketing actions more carefully.

Social media marketing ROI is a topic much discussed in managerial marketing literature. Blanchard (2011) draws a clear distinction between financial and non-financial outcomes of social media marketing. Financial outcomes are cost reductions or increased revenue, which must be measured in currency. ROI measurement is always a measurement of financial outcomes. Turner and Shah (2001) additionally propose that ROI must be measured in currency, but their opinion is slightly broader. To ease ROI measurement they propose companies use metrics such as customer lifetime value and cost per acquisition (CPA). They argue that by knowing CLV and CPA it is easy to calculate ROI. Arikan (2008) underlines that qualitative and quantitative metrics are intermediary indicators, while ROI metrics are the only truly reliable 
performance indicators. Delahaye Paine (2011) lists five ways to measure social media marketing ROI: sales or revenue, cost savings, paid versus earned search rankings, cost avoidance, and social capital (cost savings for example through customer service in social media).

Hanna et al. (2011) propose that social media marketers should focus on conversion tracking of downstream metrics such as sales and brand engagement. This means that marketing managers should define the key outcomes of a certain marketing campaign and quantify the relevant metrics (e.g., sales, reach, brand mentions, leads) to measure those outcomes. To avoid the situation where a company measures only the results they are seeking, it is worth remembering that marketing objectives should be considered as a starting point of the measurement process. If the measurement process focuses straight in on conversion tracking, the broader picture might be overlooked.

Barlow and Thomas (2011) present 22 social media marketing metrics in five categories. The categories are based on a five step sales funnel: exposure, influence, engagement, action / conversion, retention. Blanchard (2011) lists 55 metrics and sub-metrics to measure social media marketing and ten metrics (total volume of mentions, sentiment mix for mentions, SMS/text activity data, email activity data, traditional mail response data, retail store traffic, net transacting customers, net number of transactions, net revenue, and other conversion data) as management level key performance indicators. He underlines that all data the company gathers should measure the impact of the company's marketing activities on consumer behaviour. Turner and Shah (2011) list 20 metrics for social media marketing, but they note that those are only some of the metrics available. They categorize social media measurement metrics in three groups: measurement of quantity (e.g. number of followers, number of links, click-though rates), 
measurement of quality (e.g. sentiments, thoughts, emotions, feelings), and measurement of ROI (e.g. leads generated, customers retained, prospects converted, profits generated). Similarly, Arikan (2008) categorizes 17 online marketing metrics in three groups (qualitative, quantitative, ROI). Against this backdrop, we unify the metrics lists of Barlow and Thomas (2011), Blanchard (2011), Turner and Shah (2011), and propose 33 different metric to measure social media marketing (Table 1).

\section{"Take in Table 1 about here"}

Most marketing managers struggle to analyse a large number of metrics on a weekly basis, so a company has to choose the best metrics for each objective and situation. To do that it is important to categorize the metrics in groups. Based on our conceptual discussion, we categorize the different social media marketing performance metrics in Figure 1 in three groups labelled qualitative, quantitative and financial (ROI).

"Take in Figure 1 about here"

\section{Conclusions}

The objective of this study was to create a framework for measuring the effectiveness of social media marketing communications. We asked whether the existing marketing communications performance metrics are still valid measures of the effectiveness of social media marketing. By drawing upon literature on marketing performance metrics, social media marketing, and social media metrics we proposed a framework (Figure 1) for assessing the available social media marketing performance metrics.

Social media has become a popular research topic among marketing academics in a short time (e.g. Kietzman et al., 2011; Dennis et al., 2009; Liu et al., 2011). Although the concept of social media is still in its infancy, during the last ten years the topic has been studied from 
several standpoints. Our review of the literature reveals that social media marketing is customercentred - its key elements being UGC and customer interaction (van Zyl, 2009; Riegner, 2007). It seems obvious that social media literature is constantly growing and enhances its popularity among business practitioners and academics in future.

When companies engage with their customers, the focus of their marketing measurement should be on the customer reaction to the tactics employed by their marketers. The digitized environment facilitates reaction tracking and marketing communications measurement. In the light of the findings of the study, we propose that marketing measurement models developed in the past 40 years are still usable, and even more important than ever. The shift towards a digitized interactive marketing environment does not necessarily mean that a whole array of new measurement metrics is needed.

Discussion of marketing performance measurement has deep roots in marketing history. Since the 1940s, writers have searched for the best ways to establish the results and benefits accruing from marketing actions (Seth and Sisodia, 2002). The marketing performance measurement discussion was initially focused on cost analysis and auditing (Seth and Sisodia, 2002), but later shifted to market orientation and especially customer orientation (Rust et al., 2004). The typical metrics employed in cost analysis are profits and savings; with market orientation, they are shareholder value, brand equity and market share; while with customer orientation they are CLV, CP and customer satisfaction.

The digitalization and social media technologies have enlivened the discussion around marketing performance measurement during the last ten years (Gleaves et al., 2008; Phillips and Halliday, 2008). New technologies enable more precise qualitative and quantitative marketing communications measurement and on the other hand executive boards want tangible results from 
marketing actions. The latter might be also the reason why many marketing authors have asked for more synergy between marketing and accounting (e.g. McManus and Guilding, 2008; Seth and Sisodia, 2002; Lukas et al., 2005; Phillips and Halliday, 2008).

We found that the marketing communications measurement must be company specific (Seth and Sisodia, 2002) and have its roots in the company's business strategy (Phillips and Halliday, 2008). Measurement practices should examine how both long-term objectives and short term objectives are met (Ambler and Roberts, 2008). Especially in the social media context, but also in a broader sense, marketing performance should be measured with several metrics. Metrics should be high level, necessary, sufficient, unambiguous, and ideally, predictive. Thus, marketing metrics should be calculable, in quantitative form, and auditable that is, reliable and professionally sourced (Ambler, 2002).

According to our research there is no broadly accepted opinion of a single key performance indicator (KPI). Many authors have classified social media marketing metrics in three groups: qualitative, quantitative and financial (ROI) (see e.g. Arikan, 2008; Turner and Shah, 2011). Based on our literature review this classification could be useful, but more research is needed in the future. In any case, through social media measuring, monitoring and searching, companies can gather both quantitative and qualitative data. The relationship between qualitative metrics and ROI metrics should be investigated carefully.

Because marketing communications in social media is customer-oriented (or even customer driven), marketing measurement metrics should also be customer oriented. In our literature review we noticed that metrics to measure marketing communications performance has developed towards a customer orientation. Metrics like CP, CLV and CE have won favour from 
many authors (see e.g. McManus and Guilding, 2008; Sidhu and Roberts, 2008; Zahay and Griffin, 2010; Arikan, 2008; Blanchard, 2011).

\section{Limitations and further research}

It is necessary to point out that our analysis is not without its limitations. For example, a large share of the literature concerning social media marketing measurement is managerial in nature. Our study can also be considered as a pioneering study attempting to combine traditional marketing performance literature and social media marketing literature. Thus, the results presented are merely indicative rather than conclusive. Given the early stages of the literature concerning the measurement of social media marketing, it was also difficult to draw robust conclusions about the best metrics everyone should use.

In an attempt to mitigate these limitations, we identify several fertile avenues for further research in this domain. As stated above, marketing communications performance measurement in the era of social media is a growing research topic for both academics and practitioners. For example social media monitoring, web analytics, cloud-based customer service and e-commerce might strongly develop marketing performance measurement potential. It would be interesting to study how companies have combined the increased interest both in social media and in marketing performance measurement in practice. How has the movement towards social media changed measurement practices?

In future, empirical research is needed to examine and validate social media marketing performance measurement. Empirical studies could specify and evaluate the most common metrics employed to measure marketing performance in the social media era. Further research could examine how marketers formulate their key performance metrics for social media marketing communications. An interesting question is whether the popularity of marketing 
accounting will continue to increase or perhaps we are moving towards more qualitative type of measures, or a mix of the two forms.

We believe, in line with Morgan et al. (2002) that marketing practitioners are often unable to prove and support cause and effect relationships between marketing inputs (money), tactics (actions) and outcomes (e.g. growth in profit). On the other hand, the increased research interest, the greater demand for more precise reporting from marketing managers, and especially the recent movement towards a digitized interactive business environment, make possible remarkable changes in marketing communications performance measurement. The theoretical discussion on marketing performance measurement should continue and step by step transform into practice. 


\section{References}

Aho Williamson, D. (2011), Wordlwide Social Network Ad Spending: 2011 Outlook, eMarketer Inc, New York.

Ambler, T., Kokkinaki, F., Puntoni, S., and Riley, D. (2001), “Assessing Market Performance: The Current State of Metrics”, Working Paper [01-903], London Business School Centre for Marketing, September 2001.

Ambler, T. (2002), "Market metrics: what should we tell the shareholders?", Balance Sheet, Vol. 10 No.1, pp. $47-50$.

Ambler, Tim., Kokkinaki, F. and Puntoni, S. (2004), ”Assessing Marketing Performance Reasons for Metrics Selection”, Journal of Marketing Management, Vol. 20, pp. 475-498.

Ambler, T., and Roberts, J. (2008). “Assessing marketing performance: don't settle for a silver metric”, Journal of Marketing Management, Vol. 24 No. 7, pp. 733-750.

American Marketing Association. (2005), "Marketing Accountability Study”, White Paper American Marketing Association, Chicago, ILL.

Arikan, A. (2008), Multichannel Marketing. Metrics and Methods for On and Offline Success, Wiley Publishing Inc., Indianapolis, Indiana.

Blanchad, O. (2011), Social media ROI. Managing and Measuring Social Media Efforts in Your Organization, Pearson Education Inc., Boston.

Boyd, D. M., and Ellison, N. B. (2008), "Social Network Sites: Definition, History, and Scholarship”, Journal of Computer-Mediated Communication, Vol. 13 No. 1, pp. 210-230.

Brown, J. O., Broderick, A. J., and Lee, N. (2007), “Online Communities: conceptualizing the Online Social Network”, Journal of Interactive Marketing, Vol. 21, No. 3, pp. 2-20. 
Cheung, C. M. K., Lee, M. K. O., and Rabjohn, N. (2008), “The impact of electronic word-ofmouth: The adoption of online opinions in online customer communities”, Internet Research, Vol. 18 No. 3, pp. 229-247.

Constantinides, E., and Fountain, S. J. (2008), “Web 2.0: Conceptual foundations and marketing issues”, Journal of Direct, Data and Digital Marketing Practice, Vol. 9 No. 3, pp. 231244.

Delahaye Paine, K. (2011), Measure What Matters. Online Tools for Understanding Customers, Social Media, Engagement, and Key Relationships, John Wiley \& Sons, Inc., Hoboken, New Jersey.

Dennis, C., Merrilees, B., Jayawardhena, C., and Wright, L. T. (2009). “E-consumer behaviour”, European Journal of Marketing, Vol. 43 No. 9, pp. 1121-1139.

Donthu, N. and Yoo B. (1998), “Retail productivity assessment using data envelopment analysis”, Journal of Retail, Vol. 74 No.1, pp. 85-105

Gleaves, R., Burton, J., Kitshoff, J., Bates, K., and Whittington, M. (2008). “Accounting is from Mars, marketing is from Venus: establishing common ground for the concept of customer profitability”, Journal of Marketing Management, Vol. 24 No. 7, 825-845.

Greenyer, A. (2006), “Measurable marketing: a review of developments in marketing`s measurability”, Journal of Business \& Industrial Marketing, Vol. 21 No. 4, pp. 239-242.

Hanna, R., Rohm, A., and Crittenden, V. L. (2011). “We're all connected: The power of the social media ecosystem”, Business Horizons, Vol. 54 No. 3, pp. 265-273

Hearn, G., Foth, M., and Gray, H. (2009), “Applications and implementations of new media in corporate communications: An action research approach", Corporate Communications: An International Journal, Vol. 14 No. 1, pp. 49-61. 
Hennig-Thurau, T., Malthouse, E. C., Friege, C., Gensler, S., Lobschat, L., Rangaswamy, A and Skiera, B. (2010), “The Impact of New Media on Customer Relationships”, Journal of Service Research, Vol. 13 No. 3, pp. 311-330.

Ho, J. Y. C., and Dempsey, M. (2009), “Viral marketing: Motivations to forward online content”, Journal of Business Research, Vol. 63 No. 9-10, pp. 1000-1006.

Inglis, R. (2008), “Exploring accounting and market orientation: an interfunctional case study”, Journal of Marketing Management, Vol. 24 No. 7, 687-710.

Jeffery, M. (2010) Data-Driven Marketing. The 15 Metrics Everyone in Marketing Should Know, John Wiley \& Sons. Inc., Hoboken, New Jersey.

Kambil, A. (2008) “What is your Web 5.0 Strategy?”Journal of Business Strategy, Vol. 29 No. 6, pp 56-58.

Kaplan, A.M., Haenlein, M. (2010). “Users of ht world, unite! The challenges and opportunities of social media”, Business Horizons, Vol. 53, pp. 59-68.

Kaplan, A. M., and Haenlein, M. (2011). "Two hearts in three-quarter time: How to waltz the social media/viral marketing dance”, Business Horizons, Vol. 54 No. 3, pp. 253-263.

Karakas, F. (2009), “Welcome to World 2.0: the new digital ecosystem”, Journal of Business Strategy Vol. 30 No. 4, pp. 23-30.

Kietzmann, J. H., Hermkens, K., McCarthy, I. P., and Silvestre, B. S. (2011). “Social media? Get serious! Understanding the functional building blocks of social media”, Business Horizons, Vol. 54 No. 3, pp. 241-251.

Liu, Q. (Ben), Karahanna, E., and Watson, R. T. (2011), “Unveiling user-generated content: Designing websites to best present customer reviews”, Business Horizons, Vol. 54 No. 3 , pp. 231-240. 
Lenskold, D, L. (2003), Marketing ROI: The Path to Campaign Customer, and Corporate Profitability, McGraw-Hill, United States of America.

Lukas, B., Whitwell, G., and Doyle, P. (2005). "How can a shareholder value approach improve marketing's strategic influence?”, Journal of Business Research, Vol. 58 No. 4, pp 414422.

Marketing Science Institute. (2000), 2000-2002 Research Priorities, Marketing Science Institute, Cambridge.

Marketing Science Institute. (2002), 2002-2004 Research Priorities, Marketing Science Institute, Cambridge.

Marketing Science Institute. (2004), 2004-2006 Research Priorities, Marketing Science Institute, Cambridge.

Marketing Science Institute. (2008), 2008-2010 Research Priorities, Marketing Science Institute, Cambridge.

Marketing Science Institute. (2010), 2010-2012 Research Priorities, Marketing Science Institute, Cambridge.

McManus, L., and Guilding, C. (2008), “Exploring the potential of customer accounting: a synthesis of the accounting and marketing literatures", Journal of Marketing Management, Vol. 24 No. 7, pp. 771-795.

Moeller, L, H. and Landry E. C. (2009), The Four Pillars of Profit-Driver Marketing: How to Maximize Crativity, Accountability, and ROI, McGraw-Hill, United States of America.

Morgan, N., Clark, B.H. and Gooner, R. (2002). “Marketing productivity, marketing audits, and systems for marketing performance assessment: integrating multiple perspectives”, Journal of Business Research, Vol. 55, No. 5, pp. 363-375. 
Muñiz Jr., A. M., and Schau, H. J. (2011), "How to inspire value-laden collaborative consumergenerated content”, Business Horizons. Vol. 54. No. 3, pp. 209-217.

Ozuem, W., Howell, K. E., and Lancaster, G. (2008), “Communicating in the new interactive marketspace”, European Journal of Marketing, Vol. 42 No. 9, pp. 1059-1083.

Palmer, A., and Koenig-Lewis, N. (2009), An experiential, social network-based approach to direct marketing. Direct Marketing: An International Journal, Vol. 3 No. 3, pp. 162-176.

Parent, M., Plangger, K., and Bal, A. (2011), “The new WTP: Willingness to participate”, Business Horizons, Vol. 54 No. 3, pp. 219-229.

Peppers, D. and Rogers, M (2005), “Return on Customer: Creating Maximum Value from Your Scarcest Resource”, Singapore Marshall Cavendish.

Phillips, P., and Halliday, S. V. (2008), “Marketing/accounting synergy: a discussion of its potential and evidence in e-business planning”, Journal of Marketing Management, Vol. 24 No. 7, pp. 751-770.

Powell, G.R., Groves S.W. and Dimos, J. (2011), ROI of Social Media. How to Improve Return on Your Social Marketing Investment, John Wiley \& Sons Inc., Singapore.

Quinton, S., and Harridge-March, S. (2010), "Relationships in online communities: the potential for marketers”, Journal of Research in Interactive Marketing, Vol. 4 No. 1, pp. 59-73.

Reichheld, F. (2003), “The number you need to grow”, Harvard Business Review, Vol. 81 No. 12 pp. $46-54$.

Riegner, C. (2007), “Word of Mouth on the Web: The Impact of Web 2.0 on Consumer Purchase Decisions”, Journal of Advertising Research, Vol. 47 No. 4, pp. 436-447. 
Rust, R. T., Ambler, T., Carpenter, G. S., Kumar, V., and Srivastava, R. K. (2004), “Measuring Marketing Productivity: Current Knowledge and Future Direction”, Journal of Marketing, Vol. 68 No. 4, pp. 76-89.

Rust, R. T., Lemon, K. N., and Zeithaml, V. (2004), “Return on Marketing: Using Customer Equity to Focus Marketing Strategy”, Journal of Marketing, Vol. 68 No. 1, pp. 109-127.

Schibrowsky, J. A., Peltier, J. W. and Nill, A. (2007), “The state of internet marketing research a review of the literature and future research directions" European Journal of Marketing, Vol. 41 No. 7, pp. 722-733.

Sheth, J. and Sisodia, R, J. (2002), “Marketing productivity: issues and analysis”, Journal of Business Research, Vol. 55 No. 5, 349-362.

Sidhu, B., and Roberts, J. (2008), “The marketing accounting interface - lessons and limitations”, Journal of Marketing Management, Vol. 24 No. 7, pp 669-686.

Steffes, E. M., and Burgee, L. E. (2009). “Social ties and online word of mouth”, Internet Research, Vol. 19 No. 1, pp. $42-59$.

Sterne, J. (2010), Social Media Metrics. How to Measure and Optimize Your Marketing Investment, John Wiley \& Sons, Hoboken, New Jersey.

Sullivan, D. O. and Abela, A. V. (2007). Measurement Ability and Firm“, Journal of Marketing, Vol. 71(April), pp. 79-93.

Sullivan, D. O., \& Abela, A. V. and Hutchinson, M. (2009). “Marketing performance measurement and firm performance. Evidence from the European high-technology sector", European Journal of Marketing, Vol. 43, No. 5, pp. 843-862. 
Thomas, D.B. and Barlow, M. (2011), The Exevutive's Guide to Enterprise Social Media Strategy. How Social Networks Are Radically Transforming Your Business. John Wiley \& Sons Inc., Hoboken, New Jersey.

Turner, J. and Shah, R. (2011), How to Make Money with Social Media. An Insider's Guide on Using New and Emerging Media to Grow Your Business, Pearson Education Inc., Upper Saddle River, New Jersey.

Vorhies, D. W., and Morgan, N. A. (2003), “Configuration Theory of Marketing Organization Fit with Business Strategy and Its Relationship with Marketing Performance”, Journal of Marketing, Vol. 67(January), pp. 100-115.

Weinberg, B. D., and Pehlivan, E. (2011), "Social spending: Managing the social media mix", Business Horizons, Vol. 54 No. 3, pp. 275-282.

Zahay, D., and Griffin, A. (2010), “Marketing strategy selection, marketing metrics, and firm performance”, Journal of Business \& Industrial Marketing, Vol. 25 No. 2, pp. 84-93.

Zyl, A. S. V. (2009), "The impact of Social Networking 2.0 on organisations", The Electronic Library, Vol. 27 No. 6, pp. 906-918. 


\section{List of figures}

Figure 1 Conceptual model of social media marketing measurement

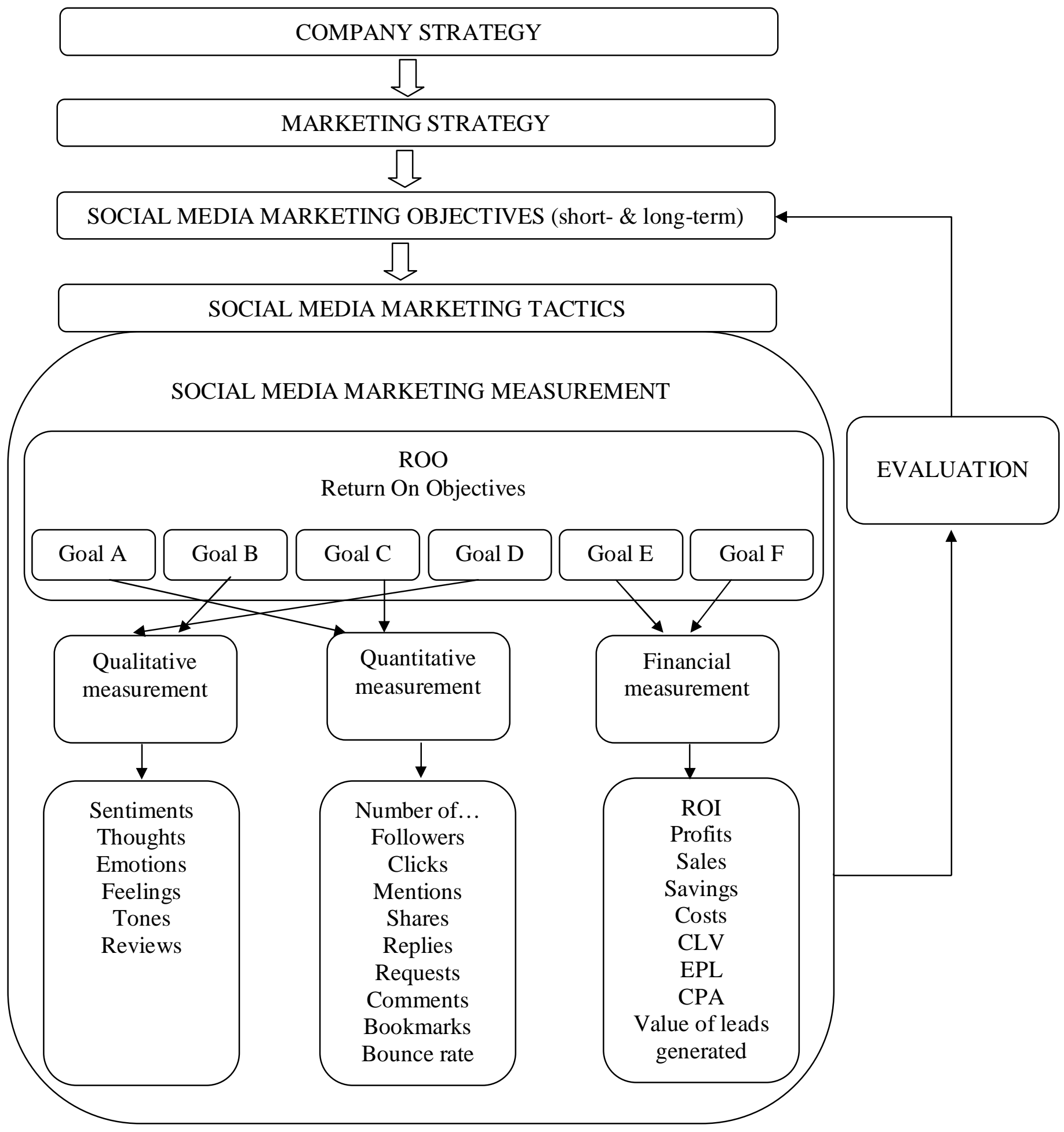


Table 1

\begin{tabular}{|l|l|l|}
\hline Qualitative Metrics & Quantitative Metrics & Financial Metrics \\
\hline Negative mentions & Number of shares & Average buy \\
\hline Positive mentions & Number of retweets generated & Average yield per transaction \\
\hline Recommendations & Number of outbound replies & ROI \\
\hline Product reviews & Number of click-throughs & EPL = earnings per lead \\
\hline $\begin{array}{l}\text { Geographic distribution of } \\
\text { mentions }\end{array}$ & $\begin{array}{l}\text { Number of customer service } \\
\text { requests }\end{array}$ & Customer lifetime value \\
\hline Consumers thoughts & Number of comments & Cost per acquisition \\
\hline Consumers feelings & Frequency of transaction & Value of online transactions \\
\hline & Number of bookmarks & Value of sales \\
\hline & Number of inbound visits & Value of conversions \\
\hline & Number of subscribers & CPM \\
\hline & Number of event attendees & Value of leads generated \\
\hline & Bounce rate & Value of prospects converted \\
\hline & Conversions & Value of customer retained \\
\hline & & Costs \\
\hline
\end{tabular}

